\title{
Book Reports
}

\section{Islamic Microfinance: Shari'ah compliant and sustainable?}

Author(s): Malcolm Harper and Ajaz Ahmed Khan (Editors).

Malcolm Harper is an emeritus professor of Cranfield University. He is an independent researcher, writer, and teacher who works mainly in India. He has published on enterprise development and microfinance. He has researched and advised on microfinance widely and has advised Islamic microfinance institutions in Sudan, Somalia, Yemen, Pakistan and India. He was Chairman of Basix Finance from 1996 until 2006, and is Chairman of M-CRIL, the microfinance credit rating agency and business development, and author of numerous books and articles. He is the co-editor of What's Wrong with Microfinance? (Practical Action, 2007).

Ajaz Ahmed Khan is Senior Microfinance Adviser, with CARE International. He holds a PhD in Development Economics and has two decades of field experience from working in countries as diverse as Honduras, Nicaragua, Ecuador, Bosnia \& Herzegovina, Kosovo, Pakistan and Sudan. He has helped to create and develop microfinance programs that provide loans and other financial services to thousands of low-income people. He has written extensively on microfinance, particularly Islamic microfinance, as well as more broadly on faith and development.

Publisher: Practical Action Publishing

Number of Pages: XIV, 220

Date/Year of Publication: 2017

ISBN: 978-1-85339-956-5

eBook ISBN: 978-178-044956-2

\section{Book Report:}

Microfinance institutions are today reaching hundreds of millions of clients throughout the global South, but the special needs of Muslim borrowers and savers, who wish to avoid any form of fixed interest, are badly served. The purpose of Islamic Microfinance is to introduce readers to the tenets of Islam and how they are applied to microfinance. It questions why, when mainstream Islamic finance is growing rapidly, are efforts to reach poor Muslim customers so far behind? Can Islamic microfinance as it grows maintain its original spirit of fairness, transparency and sharing, principles that seem to have been almost forgotten in the world of conventional microfinance?

The book contains fifteen detailed case studies of individual Islamic microfinance institutions, which include examples of successful and unsuccessful clients, and financial data about the performance of the institutions themselves. The case studies include institutions from Yemen, Afghanistan, Pakistan, India and Bangladesh, Indonesia, Sudan, Somalia, Kyrgyzstan, Palestine, and Kosovo. The institutions ranged from relatively small non-governmental organizations with a few hundred borrowers to large commercial institutions, such as the Islami Bank in Bangladesh which has almost one million clients. The book focuses specifically on the operating methodologies they employ, the challenges they face and their levels of financial self-sustainability.

The case study institutions are between them using a wide range of Sharīah-compliant financing methods, which include pure interest-free loans, profit-sharing products and a variety of other tools, including micro-savings as well as micro-debt. In the 
accompanying commentary the editors critically examine the performance of the fifteen institutions and demonstrate how Islamic methods can efficiently satisfy the needs of some types of client but not all. It asks which types of products are affordable and beneficial, for which purposes and for whom. [Prepared by Yahya Malik]

\section{Table of Contents}

Preface

1. Islamic financing principles and their application to microfinance (Ajaz Ahmed Khan, Bridget Kustin, and Khalid Khan)

Part I: Qard hasan: pure Islamic microfinance

2. Is it possible to provide qard hasan and achieve financial self-sustainability? The experience of Akhuwat in Pakistan (Ajaz Ahmed Khan, Muhammad Shakeel Ishaq, Joana Silva Afonso, and Shahzad Akram)

Part II: The predominance of murabaha

3. Pioneering Islamic microfinance in Kosovo: the experience of START (Ajaz Ahmed Khan and Vehbi Zeqiri)

4. The Islami Bank Bangladesh's Rural Development Scheme: 'need-based banking rather than greed-based micro-banking'? (Mohammed Kroessin)

5. Providing an Islamic alternative: the experience of Mutahid in Afghanistan (Hashmatullah Mohmand)

6. The murabaha syndrome: Reef and Islamic microfinance in Palestine (Ajaz Ahmed Khan and Mohammed Elayyan)

7. The experience of Kaah Islamic Microfinance Services in Somalia (Abdi Abdillahi Hassan)

Part III: Institutions providing a range of Islamic financing arrangements

8. Al Amal Microfinance Bank in Yemen: financial services in times of war (Abdullah AlKassim)

9. The experience of Kompanion-Invest in the Kyrgyz Republic (Zamir Pusurov)

10. Ebdaa Microfinance Bank: musharaka for small-scale farmers in Sudan (Nawal Magzoub Abdallah)
11. The Port Sudan Association for Small Enterprise Development in Sudan: an NGO 'project' and now a profitable business (Layla Omer Bashir)

Part IV: Institutions that also promote (some) profit and loss sharing

12. BASIX in Mewat, India: an Islamic experiment by a major Indian microfinance institution (Syed Zahid Ahmad, Anoop Kaul, and S.N. Rahaman)

13. MicroDahab in Somalia: a subsidiary of Africa's largest remittance company (Mohamed Ahmed Liban)

14. The Al Khair Co-operative Credit Society: a co-operative Islamic microfinance institution (Najmul Hoda)

15.Profit and loss sharing with smallholder farmers in Indonesia: the experience of PT Vasham Kosa Sejahtera (Irvan Kolonas and Timothy E. Rann)

16. Co-operative Islamic microfinance: Daarul Qur'an BMT from Jakarta, Indonesia (Rio Sandi and Ajaz Ahmed Khan)

17. What do the cases tell us? (Malcolm Harper) Index

\section{Antifragility of Islamic Finance: The Risk- Sharing Alternative}

Author(s): Umar Rafi and Abbas Mirakhor.

Umar Rafi specializes in the field of information technology in the financial services domain. He is currently working as a computer scientist in Silicon Valley. He has a BS in mathematics from the United States Air Force Academy, an MS in computer science from Wichita State University, and a $\mathrm{PhD}$ in Islamic finance from the International Centre for Education in Islamic Finance (INCEIF).

Abbas Mirakhor joined INCEIF in 2010 as Distinguished Scholar and the first holder of INCEIF's chair in Islamic finance. His research interests include conventional and Islamic economics and finance. Prior to joining INCEIF, he spent 24 years with the International Monetary Fund, serving as executive director and dean of the executive board. $\mathrm{He}$ is a graduate of Kansas State University, where he received his Bachelor, Master and $\mathrm{PhD}$ degrees in Economics. 
Publisher: Peter Lang Publishing

Number of Pages: 220

Date/Year of Publication: 2017

ISBN: 978-1433143502

\section{Book Report:}

Antifragility of Islamic Finance: The Risk-Sharing Alternative explains how risk-sharing, as defined under Islamic finance, makes financial systems antifragile. It highlights the benefits of $100 \%$ equitybased finance over debt-based finance.

The recent financial crisis has given rise to discussions on a new approach to risk management called antifragility. This concept specifies conditions under which systems become resilient to shocks caused by Black Swans - highly unpredictable outlier events that have a major negative (or positive) consequence when they occur, with their occurrence only explained retrospectively. Per this concept, the longterm survivability of any system centers exclusively on its antifragile nature, that is, its ability to absorb and even benefit from Black Swan-type shocks. This book aims to investigate risk-sharing Islamic finance as an antifragile system.

As a by-product of the Great Recession, the problems of debt-based financial systems are starting to be highlighted by industry and by academia. The antifragile solution for avoiding future financial crises is primarily centered on moving the existing financial system towards more equity and less debt, thereby introducing skin-in-the-game into financial transactions. This book introduces a model of a $100 \%$ equity-based financial system, centered on risk sharing, as a possible alternative to the contemporary debt-based, conventional financial system, which is based on risk transfer and on risk shifting. In essence, this book attempts to provide a practical model for an antifragile financial system by evaluating the characteristics of Islamic finance under the criteria of antifragility. [Prepared by Yahya Malik]

\section{Table of Contents}

List of Abbreviations

Glossary

Foreword

Prologue
1. Introduction

2. The Inconsistencies of Financial Modeling

3. Introduction to Antifragility

4. Debt and Destruction

5. Risk and Reward

6. A Tale of Two Bubbles

7. Epistemological Foundation of RSIF

8. Risk-Sharing Islamic Bank Structure

9. Risk Management for Risk-Sharing

10. The Islamic Finance Antifragility Framework

11. Regulating (for) the Black Swan

12. Of Ptolemy and Alchemy

Bibliography

Index

3. Islamic Capital Markets and Products: Managing Capital and Liquidity Requirements Under Basel III

Author(s): Simon Archer and Rifaat Ahmed Abdel Karim (Editors)

Simon Archer is a visiting professor at the ICMA Centre, the ground-breaking collaboration between the securities industry and Henley Business School, University of Reading (also UK). In addition to teaching, he has served as a consultant to the Accounting and Auditing Organization for Islamic Financial Institutions (AAOIFI) and the Islamic Financial Services Board (IFSB). In 2010, the Central Bank of Bahrain and Kuwait Finance House - Bahrain presented Professor Archer with a special award to recognize his contributions to the field of Islamic Finance. In addition to being co-editor of Takaful Islamic Insurance: Concepts and Regulatory Issues and co-author of Islamic Finance: The New Regulatory Challenge, Second Edition (published by Wiley), Professor Archer is also co-author of the CCH International Accounting/Financial Reporting Standards Guide and the author of a considerable number of academic papers on international accounting and on accounting, finance, and related issues in Islamic financial institutions.

Rifaat Ahmed Abdel Karim was previously the CEO of the International Islamic Liquidity Management Corporation (IILM). He is a globally respected pioneer in the development of Islamic finance, and 
served as the inaugural Secretary General at both the Accounting and Auditing Organization for Islamic Financial Institutions (AAOIFI) and the Islamic Financial Services Board (IFSB). Professor Karim received the 2016 Malaysian Royal Award for Islamic Finance. In addition to international recognition of his academic publications, which are mainly in tierone international journals in the field of Islamic finance, he has garnered numerous accolades for his pioneering work, including the inaugural Euromoney Outstanding Contribution to the Development of Islamic Finance Award (2004) and the Islamic Development Bank Award for Islamic Banking and Finance (2010). He is the co-author of Islamic Finance: The New Regulatory Challenge, Second Edition and co-editor of Takaful Islamic Insurance: Concepts and Regulatory Issues. Professor Karim is adjunct research professor at the International Centre for Education in Islamic Finance (INCEIF), Malaysia. He is also a visiting professor at the ICMA Centre, Henley Business School, University of Reading, UK.

Publisher: Wiley

Number of Pages: 328

Date/Year of Publication: 2017

ISBN: 978-1-119-21880-7

\section{Book Report:}

Islamic Capital Markets and Products provides a thorough examination of Islamic capital markets (ICM), with particular attention to the products that they offer and the legal and regulatory infrastructure within which they operate. Since Islamic banks act as asset managers, attention is paid to the regulatory challenges which they face in the light of Basel III, as regards both eligible capital and liquidity risk management. The authors of the chapters are professionals and practitioners, and write from experience. The editors also contributed to some of the chapters.

The markets and products covered include Islamic equities, Islamic investment certificates (șukūk) which are Sharī'ah compliant alternatives to conventional bonds, and Islamic Collective Investment Schemes. The coverage of legal and regulatory issues includes an examination of the implications for ICM of securities laws and regulations and of Basel III, as well as collateralization issues. Sharī ah compliance aspects, in terms both of the selection criteria for Islamic equities and of the 'purification' of impermissible components of income, are also examined in some detail, as are the implications of Basel III for eligible capital in general and for Sharî'ah compliant capital instruments in particular. A similar analysis is also made of the implications of the Basel III requirements for liquidity risk management and highquality liquid assets (HQLA), including Sharı̄ah compliant HQLA.

The book concludes with three case studies, two describing the ICM in Malaysia and Bahrain and a third which describes sukūk issued as Sharī ah compliant capital instruments, followed by brief concluding remarks by the editors. [Prepared by Yahya Malik]

\section{Table of Contents}

Foreword

Acknowledgments

About the Authors

1. Overview of the Islamic Capital Market (Simon Archer, Brandon Davies and Rifaat Ahmed Abdel Karim)

2. Islamic Capital Markets and Islamic Equities (Nor Rejina Abdul Rahim)

3. Sukuk - Unlocking the Potential for Economic Development (Dr. Sayd Farook and Redha Al Ansari)

4. Islamic Collective Investment Schemes (Simon Archer and Brandon Davies)

5. Legal and Regulatory Considerations Pertaining to Islamic Capital Markets (Michael J.T. McMillen)

6. Regulatory Aspects of the Islamic Capital Market and Basel III Requirements (Musa Abdul-Basser)

7. Shari'ah Foundations of Islamic Equity Investment Criteria and Purification of Investments (Mohamed A. Elgari)

8. Collateralisation in Islamic Capital Markets (Richard Thomas) 
9. Eligible Capital and Capital Instruments (Brandon Davies)

10. Regulatory Aspects of the Islamic Capital Market and Basel III Requirements - Shariahcompliant Bank Capital Instruments (Rafe Haneef)

11. Liquidity Risk Management and High Quality Liquid Assets (Simon Archer and Rifaat Ahmed Abdel Karim)

12. Malaysia's Islamic Capital Markets - A Case Study (Obiyathulla Ismath Bacha and Daud Vicary Abdullah)

13. Bahrain's Islamic Capital Markets - A Case Study (Dr Hatim El-Tahir)

14. Sukuk Issued as Regulatory Capital Instruments for Basel III Compliance - A Case Study (Abdullah Haron)

15.Concluding Remarks (Simon Archer and Rifaat Ahmed Abdel Karim)

Appendix A: Nominate Contracts Employed as a Basis for Shari'ah Compliant Financial Transactions

Appendix B: A Note on Market Index Providers

Index

\section{Islamic Education in the United States and the Evolution of Muslim Nonprofit Institutions}

Author(s): Sabith Khan and Shariq Siddiqui

Sabith Khan is Assistant Professor at the California Lutheran University. His expertise is in American philanthropy, civil society, international development, religion and culture. He has worked across the nonprofit, for-profit and government sectors in India, UAE, and the US. He serves as a Board Member of The Community Impact Fund, a Washington DC based community foundation and is also an active member of the Association for Research on Nonprofit Organizations and Voluntary Action (ARNOVA) and the American Society for Public Administration (ASPA).

Shariq Siddiqui serves as the visiting director and assistant professor of the Muslim Philanthropy Initiative at the Indiana University Lilly Family School of Philanthropy. Shariq has a Ph.D. and M.A. in Philanthropic Studies from the Lilly Family School of Philanthropy. He also has a JD from the McKinney
School of Law at Indiana University and holds a B.A. in History from the University of Indianapolis. He is also the Executive Director of Association for Research on Nonprofit Organizations and Voluntary Action (ARNOVA). He also serves as the co-editor of the new Journal on Muslim Philanthropy and Civil Society and as the Series Editor of the Muslim Philanthropy and Civil Society Book Series published by Indiana University Press. He has served as a nonprofit practitioner for over 20 years for international, national, regional, and local nonprofit organizations.

Publisher: Edward Elgar

Number of Pages: 168

Date/Year of Publication: 2017

ISBN: 978-1-78897-492-9

eBook ISBN: 978-1-76843-480-7

DOI: $10.4337 / 9781786434807$

\section{Book Report:}

This book is a novel and ambitious attempt to map the Muslim American nonprofit sector: its origins, growth and impact on American society. Using theories from the fields of philanthropy, public administration and data gathered from surveys and interviews, the authors make a compelling case for the Muslim American nonprofit sector's key role in America. They argue that in a time when Islamic schools are grossly misunderstood, there is a need to examine them closely, for the landscape of these schools is far more complex than meets the eye.

The authors, who are both scholars of philanthropy, examine how identity impacts philanthropy and also the various forces that have shaped the landscape of Muslim American giving in the US. Using a comparative method of analysis, they showcase how this sector has contributed not only to individual communities but also to the country as a whole. National surveys and historical analysis offer data that is rich in insights and offers a compelling narrative of the sector as a whole through its focus on Islamic schools. The authors also critically examine how nonprofit leaders in the community legitimize their own roles and that of their organizations, and offer a compelling and insightful examination of how Muslim American leaders perceive their own role in institution building. [Prepared by Yahya Malik] 


\section{Table of Contents}

Foreword: Evolution of religious nonprofits in the US: a brief history (David C. Hammack)

Preface

1. Introduction

2. Islamic Philanthropy as a discursive tradition

3. Muslim Philanthropy and Nonprofit Institutions in America

4. Identification and American Muslim philanthropy

5. Philanthropy, Institution Building and Legitimacy in Islamic Schools in America

6. Interlocutors of tradition or signposts of the future of Islam in America? : Islamic Schools in the US

7. Conclusion: prospects for future growth and development

Glossary

Index

\section{Forward Lease Sukuk in Islamic Capital Mar- kets: Structure and Governing Rules}

Author(s): Ahcene Lahsasna, M. Kabir Hassan, Rubi Ahmad.

Ahcene Lahsasna is currently Vice President of Research \& Publication at the Malaysian Financial Planning Council (MFPC) and Academic Director of the Singapore Islamic Finance Academy (SIFA). Previously, he was an Associate Professor at the International Centre for Education in Islamic Finance (INCEIF) Malaysia, also known as the Global University of Islamic Finance. Professor Lahsasna is a registered Shariah Advisor at Bank Negara Malaysia and Securities Commission Malaysia. He acts as a Shariah Advisor for Islamic banking, Islamic capital market, Takaful, and Re-Takaful locally and internationally.

M. Kabir Hassan is Professor of Finance in the Department of Economics and Finance at the University of New Orleans, USA where he currently holds two endowed Chairs - Hibernia Professor of Economics and Finance and Bank One Professor in Business.
Professor Hassan is the winner of the 2016 Islamic Development Bank (IDB) Prize in Islamic Banking and Finance. He received his B.A. in Economics and Mathematics from Gustavus Adolphus College, Minnesota, USA, and his M.A. in Economics and $\mathrm{Ph}$.D. in Finance from the University of NebraskaLincoln, USA.

Rubi Ahmad is an Associate Professor of Finance and Banking and current Deputy Dean of Research and Development in the Faculty of Business and Accountancy (FBA) at the University of Malaya, Kuala Lumpur, Malaysia. She holds a Ph.D. in finance from the Department of Accounting and Finance at Monash University, Melbourne, Australia and an MBA with a specialization in finance from the University of Memphis, Tennessee, USA.

Publisher: Palgrave Macmillan

Number of Pages: XVII, 285

Date/Year of Publication: 2018

ISBN: 978-3-319-94261-2

eBook ISBN: 978-3-319-94262-9

DOI: $10.1007 / 978-3-319-94262-9$

\section{Book Report:}

This book focuses on forward lease $s u k \bar{u} k$, which is one of the most viable and dynamic Shari'ahcompliant instruments in the Islamic capital market. The idea of forward lease $s u k \bar{u} k$ is to raise funds from non-existent assets whose subject matter does not exist at the time of the sukūk issuance. This book discusses the significant features of forward lease sukūk and demonstrates its vital contribution to project construction and manufacturing within the expanding field of Islamic finance. [Prepared by Yahya Malik]

\section{Table of Contents}

1. Introduction to Sukuk

2. An Overview of Islamic Capital Market (ICM) and Sukuk Industry

3. Sukuk in Islamic Capital Market

4. Types of Sukuk, Their Classification and Structure in Islamic Capital Market

5. Theory of Ijarah, Securitization and the Concept Financial Certificate 
6. Forward Ijarah Sukuk: Concept, Issuance, Structuring and General Governing Rules

7. Major Principles, Terms and Conditions Governing Ijarah Sukuk Issuance as Practiced in the Islamic Capital Market

8. Forward Lease/Ijarah Sukuk: Issues, Challenges and Shariah Compliance

9. Ijarah Sukuk and Forward Lease SukukCase Study

10. Conclusion, Recommendation and Policy Implication

\section{Islamic Social Finance: Entrepreneurship, Co- operation and the Sharing Economy}

Author(s): Valentino Cattelan (Editor).

Valentino Cattelan received his Ph.D. in Law \& Economics, in 2009 from the School of Economics R. M. Goodwin, University of Siena. He is currently Associate Researcher at the Saudi-Spanish Center for Islamic Economics and Finance (SCIEF), IE Business School, Madrid (Spain). His research activity covers aspects of legal and financial pluralism, property rights theory, history and anthropology of capitalism, Islamic finance regulation, comparative law and social finance. From 2010 to 2013 he was Academic Coordinator of the European project Integrating Islamic Finance in the EU Market and Lecturer in Islamic Law, Economics and Finance at the University of Rome Tor Vergata (Italy). In the academic year 2013-2014 he became Visiting Fellow at the Oxford Centre for Islamic Studies (University of Oxford, UK), under the SC-OCIS Scholar in Residence Programme in Islamic Finance.

Publisher: Routledge

Number of Pages: 222

Date/Year of Publication: 2018

ISBN: 978-1-13-828030-4

eBook ISBN: 978-1-31-527222-1

\section{Book Report:}

The current dynamics of world economy show remarkable changes in the socio-economics of credit provision and entrepreneurship. If the emergence of the sharing economy is fostering innovative models of collaborative agency, networking and venture business, economic actors are also looking for a more sustainable development, able to foster profitability as well as community welfare. This book investigates Islamic social finance as a paramount example of this economy under change, where the balance between economic efficiency and social impact is contributing to the transformation of the market from an exchange- to a community-oriented institution.

The collected essays analyze the social dimension of entrepreneurship from an Islamic perspective, highlighting the extent to which the rationales of "sharing", distribution and cooperation, affect the conceptualization of the market in Islam as a place of "shared prosperity". Moving from the conceptual "roots" of this paradigm to its operative "branches", the contributing authors also connect the most recent trends in the financial market to Sharīah-based strategies for community welfare, hence exploring the applications of Islamic social finance from the sharing economy, FinTech and crowdfunding to microcredit, waqf, zakāh, sukūk , and green investments.

An illuminating reference for researchers, practitioners and policy-makers dealing with the challenges of a global market where not only is diversity being perceived as a value to be fostered, but also as an important opportunity for a more inclusive economy for everybody. [Prepared by Yahya Malik]

\section{Table of Contents}

Foreword (Abdullah Qurban Turkistani)

1. Introduction. Islamic social finance and the importance of roots (Valentino Cattelan)

Part I - Islam, shared prosperity and the market as socio-economic community

2. From the ontology of tawhid to Islamic social finance: conceptualization and application (Masudul Alam Choudhury, Ari Pratiwi and Mohammad Shahadat Hossain)

3. A critical appraisal of Islamic finance in the light of maqasid al-Shari 'ah (Atiq-ur-Rehman)

4. Collaborative governance, social capital and the Islamic economic organization (Charilaos Mertzanis)

5. Experiences in Translation: Islamic finance and the sharing economy (Valentino Cattelan) 
Part II - Social impact entrepreneurship: instruments and cases

6. A new form of global asset-backed debt market through sukuk (Mohamed Ariff)

7. Islamic entrepreneurship and the fundraising challenge: unlocking capital via crowdfunding in the sharing economy (Houssem eddine Bedoui and Rami Abdelkafi)

8. Islamic FinTech and the paradigm shift in the financial landscape (Fatima Z. Bensar and Gonzalo Rodríguez)
9. Islamic green finance: a new path to environment protection and sustainable development (Marianella Piratti and Valentino Cattelan)

10. Salam finance: securing the purpose of microfinancing (Atiq-ur-Rehman)

11. Waqf based takaful model: a challenge for entrepreneurship (Germán Rodríguez-Moreno)

12.Zakat: its micro-entrepreneurship model and socio-humanitarian impact (Mohd Ma'Sum Billah) 